Poznań

\title{
Teoretyczne wyznaczniki zmiany systemowej w Unii Europejskiej 2014-2019
}

\section{Wstęp metodologiczny}

Celem niniejszego artykułu naukowego jest przede wszystkim identyfikacja oraz definicyjna analiza wybranych pojęć (głównie o charakterze neoidealistycznym) pomocnych w wyjaśnieniu zmian zachodzących w systemie integracji i Unii Europejskiej. Przy tak sformułowanym celu badawczym istotne dla autora stało się stworzenie koniunktywnego schematu pojęciowego służącego do przygotowania empirycznych antykryzysowych strategii i scenariuszy zmian systemowych. Schemat ten jest szczególnie ważny w kontekście metodologicznej architektoniki czystego rozumu zaproponowanej przez I. Kanta w jego dziele Krytyka czystego rozumu. Podstawą tej architektoniki jest proces poznania rozumowego z uszeregowanych pojęć - układających się w jeden zwarty systemat analityczny (Kant, 2009, s. 656-659).

Warto podkreślić, że proces wyróżniania wyznaczników (pojęć) związanych ze zmianą systemową w Unii Europejskiej obywać się musi przy zachowaniu uważności metodologicznej - zarówno tej jakościowej, jak i ilościowej. Uważność na użytek niniejszej analizy jest otwartą i receptywną świadomością naukową konsekwencji nieustannie następujących po sobie funkcjonalności i dysfunkcjonalności w systemie Unii Europejskiej, zarówno o charakterze wewnętrznym, jak i zewnętrznym.

Z uwagi na powyższe kolejne założenie metodologiczne tego tekstu opiera się na przekonaniu autora, że zmiana mająca charakter przekształcania (regulacji, jak i transformacji) powinna dokonywać się głównie pod wpływem teorii, idei i wizji czy też konkretnych wyznaczników, a nie wciąż zmiennych i reaktywnych (polityka „tu i teraz”) działań politycznych aktorów/podmiotów uczestniczących w procesie integracji europejskiej. W związku z tym wyróżnione tu pojęcia mogą być inspiracją strategiczną i/lub taktyczną dla decydentów, którzy zdecydują się lub nie na konkretne antykryzysowe zmiany w systemie Unii Europejskiej w latach 2014-2019. Czas ten bez watpienia będzie okresem przejściowym od starego systemu do nowego - nieprzewidywalnym i szczególnie podatnym na perturbacje i real-egoizmy instytucjonalne i narodowe (Wallerstein, 2008, s. 88).

\section{Sytuacja graniczna}

Poważny kryzys zaufania będący konsekwencją wielu dysfunkcjonalności strukturalnych Unii Europejskiej doprowadził do sytuacji zagrożenia dla istnienia całego pro- 
jektu integracyjnego. Unia Europejska znalazła się w krytycznym położeniu, które za K. Jaspersem nazwać można sytuacją graniczna. Charakteryzuje się ona niepokojem o przyszłość i zagrożeniem egzystencjalnym. Zerwany został stały związek między myślą a praktyką integracyjną. Poważne zmiany w organizacji społeczeństw europejskich spowodowane kryzysem integracyjnym (głównie w wymiarze ekonomiczno-finansowym) zaczęły wywoływać negatywne następstwa w świadomości publicznej. Ich rezultatem stał się deficyt odpowiedzialności wynikający z przekonania o braku wpływu obywateli UE na otaczającą rzeczywistość, a tym samym na ustanawianie ponadi pozanarodowych prawd (zasad) oraz praw/regulacji. Nastał ponury czas rozchodzenia się idei i realności (rzeczywistości/praktyki). Egoizm i protekcja narodowa na nowo pojawiły się w słowniku integracji europejskiej.

Metaforycznie do związku między myślą a praktyką odnosi się S. Mrożek w swoim Dzienniku, zastanawiając się nad znaczeniem zdania: „a słowo ciałem się stało”. Próbuje nam wytłumaczyć, że to, iż słowo ciałem się stało, to jest właśnie cud. Cudem też była i jest tak dalece zaawansowana integracja Europy. Najpierw coś zapowiedziano, a potem się to spełniło. Dziś okazuje sięjednak, że Europa dąży w kierunku całkiem odwrotnym, w kierunku zniweczenia słowa, w kierunku rozdzielenia słowa od ciała (Mrożek, 2011, s. 408).

Rozważania na temat sytuacji granicznej (krytycznej) prowadzą nas do kolejnych myśli S. Mrożka, który odwołując się do słów S. Kierkegaarda twierdzi, że „w relacji do swoich systemów większość ich twórców przypomina ludzi, którzy budują gigantyczny zamek, ale mieszkają w szopie: oni nie żyją w swoich olbrzymich systematycznych budowlach" (Mrożek, 2011, s. 398). W sensie duchowym jest to przyczyną zasadniczego sprzeciwu. Duchowo i ideowo rzecz ujmując, ludzka myśl, także ta dotycząca integracji europejskiej musi być budowlą, w której się żyje, inaczej wszystko staje na głowie (Dru, 1938, s. 143).

Dziś w Europie, ale też na całym świecie żyjemy w czasie narastania sprzeciwu wobec otaczającej nas rzeczywistości. Obserwujemy coraz więcej znaków, dzięki którym zaczynamy poważnie zakładać, że sytuacja graniczna prowadzić może do upadku. Nie można lekceważyć tego co dzieje się dziś w Europie. Tym bardziej, że sprzeciw i jego lekceważenie prowadzi do rozczarowania i obojętności, o której z takim przejęciem pisze S. Kierkegaard:

„Jeżeli warunki w danym czasie są takie, że prawie wszyscy prywatnie wiedzą, że cała sprawa jest zła, nie-prawdziwa, podczas gdy nikt oficjalnie tego nie powie. Podczas gdy taktyką używaną przez przywódców jest: pozwólcie nam po prostu działać dalej, zachowywać się, jak gdyby nic się nie wydarzyło, odpowiadać na każdy atak cisza, ponieważ my sami wiemy aż nadto dobrze, że cała sprawa jest zgniła, że gramy fałszywie; dlatego w tym wypadku warunki są eo ipso skazane na przegrana, zakończą się katastrofą. Tak jak mówi się, że śmierć naznaczyła człowieka, tak te warunki są symptomem, który bez wątpienia wzywa do ataku. Nie może być kwestii, że coś prawdziwszego stoi obok czegoś, co z dumą wierzy, że jest prawdą. To jest bitwa przeciwko kłamstwom. [...] Taktyka jest doskonale prosta: pozostań wobec nich całkowicie obojętny, absolutna obojętność wobec nich jest zwycięstwem. Takie myśli mają za cel wzbudzić w tobie niepokój, chcą uczynić cię tak niespokojnym, że w swoim tchórzostwie wyobrażasz sobie, że jesteś za nie odpowiedzialny, chcą wejść w ciebie za pomocą niepokoju, zrodzić w tobie myśl, że słuchałeś ich i spoczywałeś w nich, i tak dalej, i wszystko to w męce twojej odpowiedzialności. Jeżeli raz tak zaczniesz myśleć, to się źle skończy. Dlatego absolutna obojętność! Bardziej obojętne od ciebie 
miałoby być lekkie burczenie w twoim brzuchu. Albo jeszcze zostań wściekły, tak wściekły, jak jesteś, gdy człowiek wali w twoje drzwi o nieprawdopodobnej godzinie, i pędzisz i mówisz: cóż to za zachowanie etc., tzn. bądź wściekły, abyś się nie bał; ponieważ rzecza, której musisz unikać bardziej niż innych, jest strach.

Masz rację, walcząc z pokusą, by pierzchnąć, uciec daleko. Nie pomoże to przeciw cierpieniu, ponieważ myśli pójdą za tobą. Oto właściwa taktyka: nie bój się, bądź doskonale spokojny, całkowicie obojętny" (Mrożek, 2011, s. 402).

Z uwagi na powyższe przyjąć musimy założenie, że z Unią Europejską jest jak z człowiekiem, w którego życiu pojawia się punkt graniczny/krytyczny przybierający kształt muru, który wymaga radykalnej decyzji opartej na odpowiedzi na następujące pytanie: pozostać czy też nie przy realnym bezpiecznym życiu bez potrzeby eksperymentalnego osiagania wyższej (ponadnarodowej) świadomości i przekraczania dotychczasowych ograniczeń?

\section{Radykalizm i myślenie radykalne}

Radykalizm w kreowaniu myśli integracyjnej, a tym samym odwagi i nadziei nie oznacza zdecydowanego zwrotu w stronę unii politycznej i federacji europejskiej, ani też procesu nagłej renacjonalizacji. Chodzi tu raczej o zwrot w głąb istoty integracji. Łacińskie radicalis pochodzi bowiem wyraźnie od słowa radix, to znaczy „korzeń” i konsekwentnie oznacza tyle co pierwotny, zakorzeniony, dogłębny, gruntowny. Tym samym radykalizm polegać ma tu na powrocie do korzeni, do początków - do tego, co pierwotne. Unia Europejska bez korzeni nie jest w stanie oprzeć się wiatrom i skazana jest na obumarcie. W tym sensie można więc powiedzieć, że Europa będzie albo radykalna (konsekwentna, zdecydowana oraz wyrazista), albo martwa (Ryś, 2011, s. 6-13).

Myślenie radykalne filozoficznie jest wyrazem niepewności, która się objawia pod wpływem oglądu kryzysowej rzeczywistości. Jest formą preferencyjnego buntu przeciwko atmosferze końca - buntu, którego celem jest zrozumienie tego co dzieje się w Unii Europejskiej. W związku z tym tylko nowa europejska myśl (idea/wizja) może służyć pokonaniu radykalnej niepewności. Może stać się siła, dzięki której wyzwolona zostanie nowa nadzieja i odwaga, które przezwyciężą lęk i niepewność (Cieśla, 2013, s. 3-8).

Z myśleniem radykalnym wiąże się pojęcie radykalnej odpowiedzialności. W tym kontekście Unia Europejska musi wejść w proces dokonywania radykalnie odpowiedzialnych wyborów co do swej przyszłości. Z odpowiedzialnością radykalną wiąże się konieczność:

- ostatecznego uznania, że integracja europejska i jej wytwór instytucjonalny w postaci Unii Europejskiej to nie utopijny artefakt;

- zapełnienia luki między tym co konieczne a tym co możliwe (nowe formy integracji europejskiej i nowe formy uczestnictwa podmiotów integracji w systemie UE);

- kreacji własnej wewnętrznej i zewnętrznej siły oraz autorytetu (także moralnego);

- odrzucenia autodewaluacji tak widocznej w funkcjonowaniu unijnych instytucji (Horney, 1982, s. 145-147);

- rezygnacji z dążenia do nieograniczonego wzrostu i rozwoju na rzecz wzrostu selektywnego, pozbawionego ryzyka zapaści systemowej (Fromm, 2012, s. 234); 
- wzmocnienia sieci wzajemnej komunikacji, dialogu i porozumienia;

- przekonania obywateli UE, że bez integracji europejskiej ich życie będzie pozbawione wielu praw i przywilejów;

- pobudzania wzajemnego zaufania między ludźmi, instytucjami i państwami.

\section{Nadzieja radykalna}

Mimo, że wiek XX nie zdołał stworzyć doskonałego ustroju wspólnej Europy alternatywa „europejska utopia albo nic” nie ma dziś sensu. Dlatego też nadzieja jest na tyle ważna, żeby nadal umieszczać ją wśród celów polityki i edukacji europejskiej. Nadzieja to pozytywny stan emocjonalny, który łączymy z optymizmem, zaufaniem, poczuciem sensu oraz przeciwstawieniem się zwattpieniu. Nadzieja to czynnik motywujący i dynamizujący do aktywności na rzecz kontynuacji budowy wspólnego europejskiego projektu (Olbrycht, 2013, s. 1-10).

Kolejny kryzys Unii Europejskiej nazwany „kryzysem kryzysów”, do którego doszło w atmosferze zaburzeń strukturalnych w strefie euro sprawił, że w Europie rozprzestrzeniło się poczucie zbliżającego się końca projektu integracyjnego. Lęk przed biblijną „,bestią wychodzącą z czeluści” okazał się wszechogarniajacy. Zło zamanifestowało swe istnienie m.in. za pośrednictwem chciwości i moralnego hazardu przypisywanych kapitalizmowi integracji europejskiej. Wspólny pieniądz potwierdził jego substancjalne - materialne i osobowe istnienie (Podgórzec, 1993, s. 11). W związku z tym społeczeństwa europejskie podzieliły się na dwie grupy. Pierwsza z nich opiera się na przekonaniu, że nadchodzący upadek Unii Europejskiej zmusza do powrotu do idei państwa narodowego z ekspozycją umiarkowanego lub fundamentalnego nacjonalizmu. Reprezentanci tej grupy twierdzą, że jeżeli europejska nadzieja jest studnią na la Grand-Place w Brukseli, to można odnieść wrażenie, że ta studnia została zatruta (Delsol, 2003, s. 7). Druga zakłada jednak, że nadszedł czas na obronę za wszelką cenę tego co udało się w Europie wspólnie osiagnąć. Zwolennicy tego sposobu myślenia odrzucają apokaliptyczny strach, defetyzm i niewiarę we wspólne europejskie dobro. Wręcz odwrotnie postulują koncentrację na nadziei radykalnej, która wyzwoli w Europie nową energię. (Lear, 2013, s. 1-25). Tu z pomocą przychodzą słowa wypowiedziane w dramatycznych okolicznościach holocaustu przez dr. Janusza Korczaka, który mówił, że światu potrzebna jest nowa wiara. Europejczycy potrzebują dziś właśnie tej nowej wiary, wartości i nadziei, a także poszanowania dla człowieka/jednostki - opartych na solidnym fundamencie aksjologii judeo-chrześcijańskiej.

Z uwagi na powyższe, warto w tym miejscu skoncentrować się na przypomnieniu treści Preambuły zawartej w Projekcie Traktatu ustanawiającego Konstytucję dla Europy zaproponowanej przez Prezydium Konwentu Europejskiego (Projekt Traktatu, 2003, s. 1-50). Założono tam, że Europejczycy są już świadomi tego, że „Europa jest kontynentem, który wykształcił cywilizację, że jej mieszkańcy, przybywając kolejnymi falami od zarania ludzkości, stopniowo rozwinęli podstawowe wartości humanizmu: równość ludzi, wolność, szacunek dla rozumu”. W treści Preambuły uznano, że budując nowy ustrój Europy powinno się czerpać ,natchnienie z kulturalnego, religijnego i humanistycznego dziedzictwa Europy, które początkowo było zasilane przez cywili- 
zacje Grecji i Rzymu, charakteryzujące się duchowym impulsem nieprzerwanie obecnym w jej dziedzictwie, a następnie przez filozoficzne nurty Oświecenia, które osadziły w życiu społeczeństw postrzeganie centralnej roli ludzkiej osoby i jej nienaruszalnych i niezbywalnych praw, i szacunek dla prawa". Zaproponowano sygnatariuszom traktatu konstytucyjnego przekonanie, że zjednoczona Europa ma moralny obowiązek podążać tą drogą cywilizacji, postępu i dobrobytu, dla dobra wszystkich jej mieszkańców, również najsłabszych i najuboższych. Zadeklarowano też, że Europa „,pragnie pozostać kontynentem otwartym na kulturę, naukę i postęp społeczny, że pragnie pogłębić demokratyczny charakter swego życia publicznego, i dążyć do pokoju, sprawiedliwości i solidarności na całym świecie".

Nadzieja radykalna wiąże się także z przekonaniem, że w Europie da się zbudować większościową wspólnotę dobrych obywateli opartą na wspólnej trosce i wizji przyszłości. Wspólnotę, która nie pozwoli na dominację mniejszości, która nigdy nie zaakceptuje dzieła zjednoczenia. Bazą dla nadziei radykalnej oraz wielopłaszczyznowego myślenia zintegrowanego (swoistego meta-myślenia) muszą być nie tylko obiektywne, potwierdzone dane i fakty empiryczne [np. realny (racjonalny) bilans zysków i strat wynikający z członkostwa i nie-członkostwa w UE], ale także pozytywne emocje, symbole, skojarzenia i wizje (w tym obrazy i dźwięki).

\section{Radykalna odnowa}

Jak twierdzi S. Mrożek, ludzie nie mają odwagi ani moralnej, ani religijnej. Jego zdaniem większość jest wystarczająco przerażona możliwością tego, że każdy stanie się sobą, indywiduum (Dru, 1938, s. 143-145). To prawda, że cały rozwój świata/Europy zmierza do podkreślenia wagi indywiduum (Mrożek, 2011, s. 398). Unia Europejska ze swoim obywatelstwem, Kartą Praw Podstawowych, czterema swobodami (wolnościami) jest tego gwarantem. $Z$ drugiej strony wiemy, że aby w życiu wiodło nam się dobrze, musimy mądrze myśleć $i$ to nie egoistycznie, a kolektywnie.

Myślenie Europejczyków o wspólnotowości jest jednym z poważnych problemów współczesności. Z tego względu wyróżnić należy następujące strategie myślowe, które mogą być podstawą dla realizacji postulatów radykalnej odnowy europejskiego projektu integracyjnego:

- myślenie wspólne: praca z innymi obywatelami UE nad wspólnymi wynikami;

- myślenie szeroko-kontekstowe: wykraczanie w postrzeganiu Europy poza egoizmy i interesy (potrzeby) własne/narodowe;

- myślenie skoncentrowane: celem jest tu właściwe dostrzeganie pełni potencjału rozwojowego nie tylko w państwie, ale także strukturze ponadpaństwowej (supranarodowej, transnarodowej);

- myślenie kreatywne: myślenie wbrew schematom i politycznej poprawności poprzez dokonywanie przełomowych zmian;

- myślenie refleksyjne: oparte na prognostyce i wytyczaniu planów na przyszłość (Maxwell, 2013, s. 1-20).

Wszystkie wymienione tu strategie myślowe współkształtować mogą myślenie zintegrowane (joined-up thinking). Europa potrzebuje wspólnego (wspólnotowego) myś- 
lenia zintegrowanego, które wyzwoli potrzebę zmiany. Myślenia, które pokona wszystko to co dziś nazwać można „europejską trucizną myśli” wyrażaną poprzez: - brak zaufania obywateli do UE odbieranej przez społeczeństwo jako projekt elit (rządzących), które już od dawna budują wspólną Europę ponad głowami ludzi; - nieudolność UE w zakresie rozwiązywania podstawowych problemów obywateli UE, takich jak bezrobocie, pomoc socjalna i drożyzna; - wiara w to, że elity (bez zgody narodów i społeczeństw) budują super-państwo europejskie w miejsce dotychczasowych krajów członkowskich; - negatywny stosunek wielu ludzi do wspólnej, ale sztucznej waluty euro, której ratowanie doprowadzi Europę do bankructwa i zepchnięcia na peryferie globalnej polityki i gospodarki; - sceptycyzm wobec kolejnych etapów rozszerzania Unii Europejskiej, włączając w to niechęć wobec solidarności finansowej z nowymi członkami; - nadregulację prawną, brak klarowności i zrozumienia przepisów (postanowień) zawartych w kolejnych traktatach i aktach prawnych; - nieczytelny i nieprzejrzysty system decyzyjny poddawany w łatwy sposób wpływowi grup interesu i nacisku (lobbingu); - nieufność w stosunku do wizji Europy opartej na modelu skoncentrowanym na ultraliberalnych i wolnorynkowych ideałach w gospodarce; - wspieranie globalnego kapitału, który wpływa na ustrój gospodarczy i polityczny UE; - pozbawienie państw i narodów suwerenności oraz bezradność Unii Europejskiej wobec zagrożeń dla tożsamości państw członkowskich, przede wszystkim związanych z ekspansją islamu, w kontekście rozszerzenia UE o Turcję; - wszechobecną biurokrację, przeregulowanie i marnotrawstwo pieniędzy wpłacanych do budżetu UE przez państwa członkowskie (wysokie apanaże, nietrafione projekty, nadużycia finansowe i korupcja) (Czachór, 2013, s. 1-15).

\section{Uniwersalizm, a nie partykularyzm}

Uniwersalizm wciąż i bez końca odwołuje się do cywilizacyjnej potrzeby budowania, harmonizacji i unifikacji. Jego wyrazem była i jest ludzka potrzeba życia w zbiorowości i wspólnocie, która stanowiłaby jedną zwartą i zorganizowaną całość.

Uniwersalizm integracyjny ukształtowany głównie w XX wieku, odwołując się do ponadczasowych zasad prawa rzymskiego, demokracji starożytnej Grecji oraz wartości judeo-chrześcijańskich, bazował na zbiorowym kreowaniu rzeczywistości siłą wspólnotowego (zbiorowego) rozumu. Wytworem uniwersalistycznej myśli stała się wolność, odrzucenie wojny i agresji, solidarność oraz ochrona praw człowieka i obywatela. Uniwersalizm jako wyraz ponadczasowych wartości i prawd umożliwił posługiwanie się wspólnym instrumentarium aksjologicznym, wytwarzając przy tym katalog powszechnych praw i zasad adresowanych do państw i narodów (Wallerstein, 2007, s. 11 i nast.).

Uniwersalistycznym końcem historii przełomu XX i XXI wieku stała się neokantowska koniunkcja wiecznego pokoju i politycznego spokoju (politycznej równowagi i stabilnego rozwoju). Wpisano ją do traktatów założycielskich i reformujących (na czele z Traktatem o UE z Maastricht oraz traktatami: amsterdamskim, nicejskim i lizbońskim). Potwierdziły to w pełni słowa zawarte w preambule do Traktatu o UE, a dotyczące: 
- inspiracji kulturowym, religijnym i humanistycznym dziedzictwem Europy, z którego wynikają powszechne wartości, stanowiące nienaruszalne i niezbywalne prawa człowieka, jak również wolność, demokracja, równość i subsydiarność;

- przywiązania do zasad wynikających z poszanowania prawa i acquis communautaire;

- pogłębiania solidarności między narodami w poszanowaniu ich historii, kultury i tradycji;

- umacniania gospodarki oraz doprowadzenia do ustanowienia unii gospodarczej i walutowej wraz z jedną i stabilną waluta;

- popierania postępu gospodarczego i społecznego narodów poprzez urzeczywistnienie Rynku Wewnętrznego oraz umacnianie spójności i ochrony środowiska, przy uwzględnieniu zasady zrównoważonego rozwoju, oraz prowadzenia polityk, które zapewnią, że integracji gospodarczej towarzyszyć będzie równoczesny postęp w innych dziedzinach;

- ustanowienia wspólnego obywatelstwa (homines novi?);

- wzmacniania tożsamości i niezależności Europy w celu wspierania pokoju, bezpieczeństwa oraz postępu w Europie i na świecie;

- ułatwienia swobodnego przepływu osób, przy zapewnieniu bezpieczeństwa narodom, poprzez ustanowienie przestrzeni wolności, bezpieczeństwa i sprawiedliwości;

- kontynuacji procesu tworzenia coraz ściślejszego związku między narodami Europy, w którym decyzje są podejmowane jak najbliżej obywateli, zgodnie z zasadą pomocniczości (Preambuła Traktatu).

Odwróceniem uniwersalizmu jest partykularyzm, który umieszczony został w przestrzeni antyidealistycznej i antyutopijnej. Nie można o nim zapomnieć, zważywszy, że jedność Europy nie zawsze była elementem towarzyszącym rozwojowi cywilizacji europejskiej. Przez setki lat, ze szczególnym uwzględnieniem okresu od XVII do końca pierwszej połowy XX w. ten sposób myślenia dominował w Europie. Jego cechą był egoizm narodowy wyrażany w postaci przywiązania do realizacji własnych interesów (łącznie z ekspozycją „praw” narodów szczególnych/dominujących). Jego skutkiem było też zamknięcie (izolacjonizm), nietolerancja i dyskryminacja. Preferował jedne sprawy kosztem drugich. Eksponował egoizm i indywidualną korzyść z pominięciem dobra ogółu. Doświadczyła tego Polska w trakcie ponad 100-letnich zaborów.

$Z$ drugiej strony partykularyzm także dziś eksponuje suwerenną odrębność, niezależność i samodzielność. Uwzględnia głównie korzyść własną. W jego języku dominują takie słowa jak: własny, nasz, swój, indywidualny: interes.

Może być jednak bardzo istotny w utrzymaniu bezpieczeństwa narodowego i zbiorowego.

Dziś w kontekście kolejnych kryzysów integracyjnych partykularyzm daje o sobie znać w sposób nadzwyczaj szczególny. Był i jest obecny w:

- „wyrywaniu” się państw spod kurateli unijnych instytucji (wymykaniu się spod ich kontroli). Ofensywę rządów państw członkowskich w tym zakresie obserwowaliśmy w trakcie negocjacji traktatu lizbońskiego;

- nadmiernym eksponowaniu suwerenności narodowej i konstytucyjnych obowiązków państw;

- wzmacnianiu siły politycznej państw w trakcie prowadzonych negocjacji (np. dotyczących wieloletnich ram finansowych 2014-2020); 
- odwoływaniu się do potencjału gospodarczego państw (np. Niemcy w trakcie negocjacji nad kolejnymi pakietami ratunkowymi, głównie dla Grecji);

- narastaniu tendencji hegemonicznych w systemie integracyjnym;

- ucieczce przed odpowiedzialnością za system integracyjny ujmowany jako jedna harmonijna całość (fragmentacyjne stosunki i stany rzeczywistości) (Czachór, 2013, s. 15-30).

Należy położyć kres wszelkim partykularyzmom. Bez tego idea integracji europejskiej nie zostanie urzeczywistniona. Okres, kiedy Europa mogła się rozwijać bez czynnego udziału swoich obywateli, przy ich milczącej akceptacji odszedł do historii. Koniec lat 90-tych to powrót do praktycznego uznania, że Europa to przede wszystkim realizacja uniwersalnej demokracji, gdzie głównym celem jest człowiek. Przyszłość Unii, jej dalsze trwanie i rozwój zależy od stopnia utożsamiania się z nią jej obywateli i narodów. Taka była zawsze idea Roberta Schumana: „zanim Europa stanie się sojuszem wojskowym czy całością ekonomiczną musi być wspólnotą kulturalną w najszczytniejszym sensie tego słowa, Europa jest realizacją uniwersalnej demokracji w chrześcijańskim znaczeniu tego słowa" (Huebner, 2002, s. 2).

Europa podziela takie wspólne wartości i tradycje jak wolność osobista, prawa człowieka, tolerancja, oświecenie. Istniejące w zjednoczonej Europie granice nie tworzą linii podziału, nie zamykają, nie izolują, lecz stają się pomostem dla wymiany wartości oraz progiem dla otwartości i zrozumienia, ułatwiającym przezwyciężanie stereotypów obciążających wzajemne stosunki między narodami europejskimi. Kulturowa różnorodność narodów europejskich stanowi podstawę tożsamości Europy, ułatwia dialog między cywilizacjami, co przyczynia się do eliminacji źródeł potencjalnego konfliktu. Tożsamość europejska oznacza dziś również budowanie coraz głębszych więzi, zwiększanie konkurencyjności gospodarczej, utrwalanie europejskiego stylu życia, europejskich wartości, z wolnością jednostki na czele, w nawiązaniu do społecznej zasady solidarności. W coraz bardziej otwartym świecie, w świecie powiązanym gęstą siecią współzależności, członkostwo w Unii Europejskiej pozwala jej państwom członkowskim na jednoczesne bycie sobą i czerpanie z doświadczeń i dorobku innych. Tożsamości narodowej i kulturowej nie można dzisiaj chronić i pogłębiać w izolacji. Trzeba to robić uniwersalistycznie: pośród i wraz z innymi narodami. Unia Europejska ma to do siebie, że sprawia, iż kraje członkowskie i ich społeczeństwa zwracają się bardziej ku sobie (Huebner, 2002, s. 2-4).

\section{Rozum praktyczny i publiczny}

W tym miejscu należy odwołać się do uniwersalistycznego kantowskiego elementu rozumu praktycznego, którego jedną z naczelnych zasad jest moralny imperatyw kategoryczny. Imperatyw ten nakazuje obywatelowi Unii Europejskiej postępować zawsze według takich reguł, co do których chciałby, aby były one stosowane zawsze przez wszystkich Europejczyków w ich wzajemnych interakcjach na poziomie jednostek, jak i zorganizowanych instytucji i wspólnot (także tych ponadnarodowych). W grę zatem wchodzą idealne normy postępowania, a nie realne pobudki działań takich czy innych ludzi (państw) oraz instytucji. Tym bardziej nie może tu obowiązywać irracjonalizm 
oparty na przekonaniu, że coś jest dla Unii Europejskiej dobre, ponieważ ,ja (Niemiec, Polak, Francuz itd.) tak sądzę".

Z uwagi na powyższe każdemu Europejczykowi potrzebne są pewne zasady, które są dane rozumowi po to, aby wiedzieć jak żyć. Nie są one dowiedzione, ale konieczne są do życia w zintegrowanej wspólnocie. W koncepcji rozumu publicznego jako bazy dla pokoju i porozumienia między ludźmi zaproponowanego przez J. Rawlsa zakłada się, że obywatele Unii Europejskiej powinni myśleć o sobie tak, jakby byli unijnymi rządcami i prawodawcami i zapytywać siebie samych jakie reguły/normy (zasady), za którymi stoją konkretne racje integracyjne uznaliby za najbardziej rozsądne (zasadne) i wprowadziliby je w życie (kantowska idea umowy pierwotnej). Istotą jest tu dążenie do stanu, w którym obywatele UE robią wszystko co w ich mocy i aby to samo czynili unijni politycy i urzędnicy (Rawls, 2001, s. 84). Wynikać to musi z nakazu moralnego, a nie obowiązku prawnego zapisanego w Traktacie o Unii Europejskiej lub Traktacie o funkcjonowaniu UE.

Rozum publiczny wyraża się w na pozór prostej zasadzie, że to rządzący (skupieni w państwach i unijnych instytucjach) permanentnie i dogłębnie wyjaśniają obywatelom UE powody, dla których prowadzą lub chcą zrewidować swą politykę integracyjną. Z tego to powodu:

- większość nie może bać się krzyczącej mniejszości;

- większość nie może milczeć, gdy mniejszość krzyczy. Bierne przyglądanie się poczynaniom mniejszości nigdy niczego dobrego nie przyniosło;

- trzeba na nowo zdefiniować zbiorowość i zrozumienie siły zbiorowości (Unia Europejska tak skupiła się na elementach np. prawach jednostek - obywateli UE, że zapomniała o całości - Unii ujmowanej jako wspólnota (konstruujący się system).

\section{Zamiast zakończenia}

W społeczeństwie globalnym, szczelnie oplecionym siecią powszechnej informacji, w społeczeństwie o strukturach ,spłaszczonych”, w którym coraz większą rolę odgrywają społeczności lokalne, sformułowanie przez instytucje europejskie nowego przesłania dla obywateli krajów członkowskich jest ich racją bytu. To właśnie należy rozumieć pod pojęciem nowego modelu komunikacji społecznej. Instytucje europejskie muszą przede wszystkim zastanowić się nad takim sposobem dotarcia do rzeczywistych potrzeb obywateli, który nie pozwoli im przekroczyć cienkiej linii dzielącej „bliskość obywatela” będącą wartością traktatową od populizmu (Huebner, 2002, s. 3).

Instytucje europejskie, ale i państwa członkowskie muszą zatem skierować pod adresem obywateli przesłanie, które przekona ich do zasadności realizacji przedstawianego projektu i dotrze do nich zanim korzyści płynące z tegoż projektu zaczną oni traktować jako oczywistość. Wydaje się, że w chwili obecnej przesłanie takie powinno dotyczyć przede wszystkim dwóch kwestii: jakości życia i bezpieczeństwa publicznego. Trzeba oczywiście pamiętać, że są to niejako najbardziej „egoistyczne” aspekty życia społecznego (stąd uwaga o cienkiej linii dzielącej „bliskość obywatela” od populizmu”). Komisja Europejska, Parlament Europejski i państwa członkowskie zdają się to 
dostrzegać. Świadczą o tym liczne inicjatywy podejmowane w ostatnich latach i miesiącach. Instytucje europejskie i kraje członkowskie muszą zatem rozwinąć oba wspomniane już wątki - jakości życia i bezpieczeństwa obywateli - i formułować nowe projekty z odpowiednim wyprzedzeniem, a także przekonaniem o ich zasadności, które miałoby pewien walor edukacyjny (Huebner, 2002, s. 2-3).

Należy założyć, że w 2019 roku, w trakcie kolejnej kampanii wyborczej do Parlamentu Europejskiego, rozstrzygać się będą dalsze losy integracji Starego Kontynentu. Do tego czasu wciąż nowe zaburzenia funkcjonalne będą prowadzić do problemu kontestacji i delegitymizacji polegającej na różnie motywowanym, fragmentarycznym lub całkowitym, okresowym lub trwałym wycofaniu akceptacji państw członkowskich oraz (lub) ich społeczeństw dla UE oraz efektów jej władzy. Do przyczyn tego zjawiska będzie można zaliczyć:

- niską sprawność i skuteczność Unii w zaspokajaniu potrzeb społeczeństw oraz rozwiązywaniu problemów i konfliktów pojawiających się w praktyce integracyjnej;

- przeregulowanie (nadmiar regulacji prawnych) i „przeładowanie” systemu, a tym samym brak skuteczności i przejrzystości;

- brak rozliczania z odpowiedzialności, rozproszonej pomiędzy instytucje i konkretne jednostki;

- brak realnego europejskiego przywództwa politycznego i autorytetów;

- pogarszającą się sytuację gospodarczą państw członkowskich (głównie bezrobocie młodych);

- niczym nieograniczoną biurokratyzację instytucji publicznych (krajowych i unijnych).

W ciaggu kolejnych pięciu lat Unia Europejska musi na nowo zdefiniować swoją rolę zarówno jako budowniczego, ogrodnika, jak i stróża nocnego. Nie będzie to zadanie łatwe, gdyż Europa podzieliła się na tych, którzy radzą jej przyspieszenie federacyjne, i tych, którzy uważają, że w sytuacji powstającej postinstytucjonalnej próżni należy wrócić do idei państwa narodowego. A wymarzonej „trzeciej drogi”, w postaci finalité politique akceptowalnej przez wszystkich, jak nie było, tak nie ma.

Już w 2003 roku Jacques Derrida i Jürgen Habermas zadawali sobie pytanie, co ma być spoiwem dla Europy, która charakteryzuje się bezustanną rywalizacją pomiędzy pewnymi siebie narodami. Ich zdaniem znalezienie tego spoiwa okazało się za trudne. Uznali, że chrześcijaństwo i kapitalizm, nauki przyrodnicze i technika, prawo rzymskie i Kodeks Napoleona, mieszczański sposób życia, demokracja i prawa człowieka, sekularyzacja państwa i społeczeństwa rozprzestrzeniły się na inne kontynenty i nie stanowią już proprium - własności narodów europejskich. Na dodatek wiele elementów tego wspólnego dorobku cywilizacyjnego zostało sprzeniewierzonych, chociażby kapitalizm integracji europejskiej, który objawił się brutalną chciwością, pazernością i pychą.

Jeżeli przyjmiemy, że współczesna cywilizacja europejska osiagnęła swe dno, to nie pozostaje nic innego, jak odwołać się do prostych metod na pokonywanie zła: słowa oraz bezpośredniego kontaktu i przełamywania bezradności. W tym miejscu należy przypomnieć przepiękny prolog Ewangelii św. Jana: „Na początku było Słowo, a Słowo było u Boga i Bogiem było Słowo. Ono było na początku u Boga”. Ze słowem 
wiąże się społeczna komunikacja w bezpośredniej formule face to face, dialog, debata, otwartość, zaufanie, zgoda i harmonia.

Pierwszym etapem zmiany muszą być nowe formy europejskiej komunikacji i porozumienia, wychodzące poza dotychczasowe schematy uzgodnień instytucjonalnych, międzyrządowych i międzypartyjnych. Istotną rolę mogą odegrać tu aktorzy krajowi (głównie samorządy, także te zawodowe) oraz organizacje pozarządowe oraz wszelkie (w tym niesformalizowane) ruchy społeczne. Takie instytucje, jak Komitet Regionów oraz Komitet Ekonomiczny i Społeczny, z ich obecnymi bardzo ograniczonymi kompetencjami, składem i formami działania, nie mają racji dalszego bytu. Warunkiem powodzenia tego scenariusza muszą być otwarte granice wynikające z reguł Rynku Wewnętrznego i acquis Schengen. Unijne wsparcie muszą uzyskać wszystkie te projekty, które mają zapewnić bezpośredni kontakt i spotkanie Europejczyków między sobą. Trzeba jeszcze bardziej wzmocnić programy wymiany uczniowskiej, studenckiej i pracowniczej. Europa musi być jeszcze bardziej widoczna w sporcie, kulturze i turystyce. Drugi etap to konieczność wzmożenia innowacyjności, kreatywności, wizji, strategicznego myślenia, ale także sztuki konsekwentnego i skutecznego działania. Identyfikacja interesów państw i Unii Europejskiej nie może odbywać się w zaciszu gabinetów politycznych i dyplomatycznych. Do władzy musi dojść nowe pokolenie - nie elitarne, lecz egalitarne. Ci, którzy dziś rządzą Europą, zachowują się tak, jakby stracili wiarę w to, co sami ustanowili. Rozumieją to, co stare, ale do nowego są o wiele za słabi. W procesie zasadniczej zmiany w Europie mogą i powinny uczestniczyć również media. To przecież one mogą niwelować niechęć i nieufność do Europy, tak jak zrobiły to na przykład, wspierając członkostwo Polski w UE. Tylko razem z mediami możemy przystąpić do deliberacji na temat dalszego ciągu integracji europejskiej. Z drugiej strony ludzie mediów muszą mieć świadomość, że Unia Europejska to nie tylko prostowanie bananów, uznawanie marchwi za owoc, moc żarówek, energetyka budynków, wędzenie wędlin, rodzaje papierosów, farmakoterapia, materiał siewny, ochrona ptaszków i motylków, jakość dolno- i górnopłuków, ilość $\mathrm{CO}_{2} \mathrm{w}$ powietrzu, podatek VAT na e-booki, nie wyłączając poprawy równowagi płci wśród dyrektorów niewykonawczych spółek, których akcje są notowane na giełdzie.

Nawet jeżeli media mają prawo do krytycznego spojrzenia na Unię Europejska, muszą zdawać sobie sprawę, że należy wyraźnie oddzielić poszukiwanie sensacji i skandali od odpowiedzialnego sugerowania korekt w prowadzeniu spraw europejskich i eliminowania unijnych błędów, absurdów i niekompetencji. Poza tym praktyka udowadnia, że dla mediów tematyka Unii Europejskiej nie zawsze jest najważniejsza. A to przecież media w ramach swej misji powinny przyczyniać się do kolejnego etapu zmiany, jakim ma być powrót do edukacji europejskiej opartej na czterech elementach: edukacji o Europie, czyli prezentacji historii kontynentu i rozwoju idei europejskich oraz eksponowania kultury europejskiej jako etapu rozwoju kultur narodowych; edukacji w zakresie integracji europejskiej, czyli ukazywania procesów integracyjnych w perspektywie historycznej oraz upowszechnianiu wiedzy o instytucjach europejskich; uczeniu „europejskiego myślenia”, czyli upowszechniania fundamentalnych wartości i zasad, na których oparta jest Europa, takich jak demokracja, tolerancja, prawa podstawowe; umacnianiu wśród obywateli „europejskich kompetencji” niezbęd- 
nych do funkcjonowania każdego Europejczyka, wśród których należy wyróżnić: znajomość języków obcych, korzystanie z technologii informatycznych, umiejętność dostosowania się do zmieniającego się rynku pracy.

Ryzyko rozprzestrzenienia się nihilizmu w Europie przypomina wszechogarniająca Nicość w Niekończqcej się historii Michaela Ende. Ostatnie lata historii integracji europejskiej udowodniły, że rozchodzą się światy: ten, który został wymyślony (zaplanowany) przez ojców Europy, i ten, który realnie kształtujemy i przeżywamy. Tracimy wiarę w to, co sami ustanowiliśmy. Coraz trudniej odpowiedzieć nam (nawet tym, którzy całe życie zajmują się badaniem integracji europejskiej) na pytanie, dlaczego to się nie udaje, dlaczego dopuszcza się do takich napięć, destabilizacji i kryzysów, dlaczego tyle „mądrych głów” nie jest w stanie zapobiec tak poważnym problemom. Coraz więcej w tym wszystkim niejasności, komplikacji i niedomówień. Zaczyna dominować przekonanie, że ostatni „pełzający kryzys” jest dowodem na niedopasowanie natury człowieka do skrojonej w unijnych traktatach utopii (świata iluzji). Czy dziś obywatel Unii Europejskiej - wyborca Parlamentu Europejskiego - to ten, który sądzi o tym świecie, jaki jest, że być taki nie powinien, a o świecie, jaki być powinien, że taki nigdy nie zaistnieje?

Chyba nie trzeba dziś nikogo przekonywać, że aksjologia integracji europejskiej jest elementem przetrwania, zerwania z nihilizmem i kontynuacji dzieła integracji europejskiej. Unia Europejska nie może sobie pozwolić na katastrofę aksjologiczną. Musi wrócić do swych wartości fundacyjnych. Europejskie Dobro Wspólne mogłoby być dziś połączeniem zbiorowego interesu (politycznego i ekonomicznego) aktorów integracji europejskiej ze wspólnymi wartościami, szczególnie takimi jak jedność, równość, wolność, solidarność, sprawiedliwość i bezpieczeństwo. Na poziomie państw członkowskich i unijnych instytucji sprowadzają się one do solidarnej i jednoczesnej realizacji podjętych zobowiązań, udzielania sobie pomocy i wspólnej reprezentacji własnych interesów. To oczywiste, że wspólnota celów i wartości nie tylko bieżących, lecz także perspektywicznych może stanowić okoliczność sprzyjająca podejmowaniu kolektywnych wysiłków dla przełamania marazmu roku 2014 i tego, co przyniosą nam wybory do Parlamentu Europejskiego.

Do głównych wartości mobilizujących do zapobieżenia końca Wspólnoty zapowiedzianego na rok 2019 należą dobrobyt oraz postęp, rozwój i spójność. Do tego dochodzi zaufanie, otwartość i zrozumienie dla drugiego (innego) człowieka, narodu i społeczeństwa. W kółko i bez końca należy powtarzać, że bazą dla integracji europejskiej jest praworządność, uniwersalizm oraz niepodzielność praw człowieka i podstawowych swobód i wolności, zasada ludzkiej godności oraz respektowania przyjętych przez siebie reguł zawartych zarówno w acquis communautaire, jak i acquis politique.

Interes, pieniądz, siła i przewaga to nie wszystko... Unia Europejska oparta na wartościach nie będzie tworzyć nowych granic i linii podziału. Nie będzie zamykać, izolować, stając się mostem dla przepływu ludzi, wymiany dóbr wszelakich oraz permanentnego dialogu i komunikacji - przyczyniając się tym samym do eliminacji źródeł potencjalnego konfliktu i kryzysu. Tylko pielęgnowanie wspólnych wartości pozwoli państwom i obywatelom na jednoczesne bycie sobą i czerpanie z doświadczeń i swego dorobku. Unia Europejska nie może stracić tej niezwykłej zdolności do pomocy w zwracaniu się ludzi ku sobie (Czachór, 2014). 


\section{Bibliografia}

Cieśla A. M., Józefa Tischnera heroiczne myślenie wśród przeciwieństw świata (III), http://naturalnie.com.pl/pl/dla_filozofow/jozefa_tischnera_heroiczne_myslenie2.html/19.12.2013/.

Czachór Z. (2014), Komentarze i analizy dla Instytutu Obywatelskiego, Instytut Obywatelski, Warszawa.

Czachór Z. (2013), Kryzys i zaburzona dynamika Unii Europejskiej, Wydawnictwo Elipsa, Warszawa.

Delsol Ch. (2003), Esej o człowieku późnej nowoczesności, Wydawnictwo Znak, Kraków.

Dru A. (ed.) (1938), The Journals of Soren Kierkegaard, Oxford University Press, Oxford.

Fromm E. (2012), Mieć czy być, Dom Wydawniczy Rebis, Poznań.

Horney K. (1982), Neurotyczna osobowość naszych czasów, PWN, Warszawa.

Huebner D., Unia Europejska - otwarta na obywatela, otwarta na świat. Non-paper ws. Przyszlości Unii Europejskiej, Konwent Europejski, Bruksela 21.03.2002 r.

Kant I. (2009), Krytyka czystego rozumu, Wydawnictwo Hachette, Warszawa.

Lear J. (2013), Nadzieja radykalna. Etyka w obliczu spustoszenia kulturowego, Wydawnictwo Sic!, Warszawa.

Maxwell J. C. (2013), Myślenie kategoriami zmiany, Wydawnictwo Logos, Warszawa.

Mrożek S. (2011), Dziennik. Tom I: 1962-1969, Wydawnictwo Literackie, Kraków.

Podgórzec Z. (1993), Mój Chrystus. Rozmowy z Jerzym Nowosielskim, Wydawnictwo Łuk!, Białystok.

Olbrycht K., Wychowanie do nadziei, www.fidesetratio.org.pl/files/plikipdf/olbrycht6.pdf, 20.12.2013.

Preambuła Traktatu o Unii Europejskiej, Dz. Urz. UE 2012 C 326.

Projekt Traktatu ustanawiajacego Konstytucję dla Europy. Przyjęty w drodze konsensu przez Konwent Europejski w dniach 13 czerwca i 10 lipca 2003 roku. Przedłożony Przewodniczącemu

Rady Europejskiej w Rzymie, 18 lipca 2003 roku, Konwent Europejski, CONV 850/03.

Rawls J. (2001), Prawo ludów, Wydawnictwo Fundacja ALETHEIA, Warszawa.

Ryś G. (2011), Nadzieja w radykalizmie, „Tygodnik Powszechny”, nr 29 (3236), 17 lipca.

Wallerstein I. (2007), Europejski uniwersalizm. Retoryka władzy, Wydawnictwo Naukowe Scholar, Warszawa.

Wallerstein I. (2008), Utopistyka. Alternatywy historyczne dla XXI wieku, Oficyna Wydawnicza Bractwa „Trojka”, Poznań.

\section{Streszczenie}

Niniejszy artykuł w całości dotyczy teoretycznych wyznaczników zmian systemowych w Unii Europejskiej projektowanych na okres 2014-2019. Autor zdecydował się w nim na naukową identyfikację oraz analizę wybranych pojęć - głównie o charakterze neoidealistycznym - pomocnych w wyjaśnieniu zmian zachodzących w systemie Unii Europejskiej. Istotne dla autora stało się stworzenie koniunktywnego schematu pojęciowego służącego do przygotowania empirycznych antykryzysowych strategii, prognoz i scenariuszy zmian systemowych. Schemat ten jest szczególnie ważny w kontekście kantowskiej metodologicznej architektoniki czystego rozumu. Podstawą jest tu proces poznania rozumowego z uszeregowanych pojęć - układających się w jeden zwarty systemat analityczny. Warto zauważyć, że proces wyróżniania wyznacz- 
ników (pojęć) związanych ze zmianą systemową w Unii Europejskiej obywać się musi przy zachowaniu uważności metodologicznej - zarówno tej jakościowej, jak i ilościowej.

Z uwagi na powyższe kolejne założenie analityczne dla tego tekstu opiera się na przekonaniu autora, że zmiana mająca charakter przekształcania (regulacji, jak i transformacji) powinna dokonywać się głównie pod wpływem teorii, idei i wizji czy też konkretnych wyznaczników, a nie wciąż zmiennych i reaktywnych działań politycznych aktorów/podmiotów uczestniczących w procesie integracji europejskiej.

Słowa klucze: zmiana systemowa, sytuacja graniczna, radykalizm i myślenie radykalne, nadzieja radykalna, radykalna odnowa, uniwersalizm, rozum praktyczny i publiczny

\title{
Theoretical indicators of systemic change in the European Union, 2014-2019
}

\begin{abstract}
Summary
The entire paper is dedicated to the theoretical indicators of systemic change in the European Union, envisaged for the period from 2014-2019. The author decided to perform an academic identification and analysis of selected terms, mainly neo-idealistic terms, that are helpful when explaining the changes taking place in the EU's systems. It was important for the author to design a conjunctive conceptual framework for the purpose of developing empirical anti-crisis strategies, forecasts and scenarios of systemic changes. This framework is particularly important in the context of a Kantian methodological architecture of pure reason. This is based on a process of rational cognisance from ordered concepts, forming a single, coherent analytical system. It should be noted that the process of identifying the indicators (concepts) related to systemic change in the European Union has to take place, while maintaining methodological attentiveness both in qualitative and quantitative terms.

Therefore, the author makes another analytical assumption for this paper, on the basis of his conviction that change which occurs as transformation (regulation and reshaping) should primarily take place under the influence of theories, ideas, visions or concrete indicators, rather than the constantly changing and reactive political activities of the actors/entities participating in the European integration process.
\end{abstract}

Key words: systemic change, border situation, radicalism and radical thinking, radical hope, radical renewal, universalism, practical and public reason 